\title{
Species Composition and Visiting Frequencies of Flower Visitors of Chromolaena odorata in a Dry Zone Forest Patch of Sri Lanka
}

\author{
D. G. R. M. M. Kaushalya Rathnayake and W. M. G. Asanga S. T. B. Wijetunga \\ Department of Biological Sciences, Faculty of Applied Sciences, Rajarata University of Sri Lanka, Mihintale, Sri Lanka
}

Correspondence should be addressed to D. G. R. M. M. Kaushalya Rathnayake; kaushdx@yahoo.com

Received 18 August 2016; Revised 27 October 2016; Accepted 1 December 2016

Academic Editor: G. Wilson Fernandes

Copyright (c) 2016 D. G. R. M. M. K. Rathnayake and W. M. G. A. S. T. B. Wijetunga. This is an open access article distributed under the Creative Commons Attribution License, which permits unrestricted use, distribution, and reproduction in any medium, provided the original work is properly cited.

Plant-animal interaction has been a major theme in ecology as it has helped ecologists to rule out different patterns they observed in the surrounding environments. Chromolaena odorata is another plant species that is studied extensively as it has become a major troublesome weed in many parts of the tropics. But, handful of studies are available on pollination of this invasive plant species in dry forests and its function as a pollinator sink in these environments. The current study was carried out in a dry zone secondary forest patch in North-Central Sri Lanka to assess the diversity, abundance, and pollination strength of flower visitors associated with the C. odorata. The results suggest that the diversity of Hymenoptera and Lepidoptera is higher than the other insect orders that visited C. odorata, but all species exerted equal pollination strength on the plant. The attraction of large numbers of insects is concluded to as one of the factors that contribute to the reproductive success of $C$. odorata in dry zone forests.

\section{Introduction}

Transfer of pollen grains to the stigma of the flower gynoecium (Pollination) is the crucial event in sexual reproduction process of flowering plants that ensures their long last survival [1-3]. Therefore, self-incompatible flowering plants in the world heavily rely on animals for their pollination $[1,3,4]$. Thus, plants benefit from these mutualistic interactions to ensure effective cross pollination and to maintain viable population in their habitats.

Disturbances that alter pollinator communities in habitats where self-incompatibale flowering plants are abundant may reduce the pollination services. Additionally, loss or low abundance of pollinating partners will lead ecologically specialized plants to edge of local extinctions. These distrupting factors can be (1) human alterations to environments reducing pollinator abundance (agriculture, pesticides effect); (2) the effect of invasive, ineffective pollinator species that exclude effective native pollinators from floral resources (pollinator competition); and (3) introduced exotic flowering plants with higer attractability than native flowering plants
[5]. However, most of the pollinator communities consist of higher number of invertebrate generalists and few number of specialists who visit flower for floral resources [6-8]. Thus, tropical pollinator networks have developed an immunity against the decline of specialized pollinators but it gives no gurantee that the fidelity between interaction partners will be kept after alterations to the system occur.

Importance of pollination has been well documented. But, handful of studies are available which explore insect visitors in exotic plants while studies on controlling invasive plants are being largely available. According to our understanding, studies on plant-insect mutualism in certain weeds are extremely important as they might reveal several underlining causes to their inherent invasiveness [9] in the habitats they are invading. Among different adaptive characteristics seen in exotic invasive plant species, competing with native species for resources available in particular environment including pollinators is commonly observed [10]. This may bring a detrimental effect on native existing mutualisms. Growing as considerably large stands and mass flowering with higher amount of reward for pollinators, these exotic 
species attract pollen dependent insects that visit other native flowering plants [9]. This abundance in exotic floral resources is known to alter the spatial distribution of floral resources and by that they compete for pollinators with native selfincompatible flowering plants [5]. One of the resons that the exotic plants gets more dispersed is having high success in pollination and thereby high seed production to extend their dispersal range [11]. In contrast, several authors argue that abundance of exotic plants with high amount of floral resourses is beneficial to neighboring native plants because they increase pollinators in the area by acting as a sink [12].

A native of Central and South America, Chromolaena odorata (L.) King and Robinson, the Siam weed has spread throughout the tropical and subtropical areas of the world and is now a major weed in Central and Western Africa, South and Southeast Asia [13]. This neotropical weed is being flagged as one of the most troublesome weeds in many humid tropical countries [14]. Being perennial and having the ability to withstand dry climate, fires $[15,16]$, and stressed environmental conditions $[17,18]$ C. odorata has become more abundant weed in the above regions while showing potential extension of its distribution.

This study was conducted to assess pollinators that visit widely dispersed C. odorata in tropical secondary dry forest patch in North-Central Sri Lanka. Visitation frequencies were utilized as a surrogate to measure the importance of flowering plant to potential insect pollinators as a forage source.

\section{Materials and Methods}

2.1. Chromolaena odorata. C. odorata formerly known as Eupatorium odoratum L. is a weedy pioneering shrub [13, 16, 19]. This invasive plant has spread over South Asian region from mid-nineteenth century and currently stated as the most troublesome weed in the region $[13,14,19]$.

C. odorata is a scrambling perennial shrub, with straight, pithy, and brittle stems, usually grown up to 2-3 $\mathrm{m}$ in height. But with support from other vegetation and environmental conditions it can reach up to $5-10 \mathrm{~m}$ in height $[15,19]$. Capitula are located in panicles at the ends of the branches and are with only disk florets. Each floral head usually consisted of 21 to 28 tiny tubular florets. These flower heads are about $10 \mathrm{~mm}$ long and $3 \mathrm{~mm}$ wide, pale pink or pale mauve in color, bisexual, and actinomorphic. The ligule is tubular with five teeth at the tip. Five epipetalous stamens arise from the base of the corolla; filaments are free but anthers are united, syngenesious. The anthers are dithecous, and the pollen grains are very small, round, and ornamented. The styles of florets are stretched beyond anthers and its branches are receptive to pollen deposited by flower visitors [9]. In the end of the first growth season, the plants undergo sexual reproduction cycle producing approximately 8400 seeds $/ \mathrm{m}^{2}$ [20] and reproduction becomes majorly apomictic in later periods of the life cycle. Seeds are mainly wind-dispersed and they also exhibit the tendancy to stick to fur, feather, and clothes.

2.2. Study Site. The study was conducted in Mihintale Sanctuary where dense vegetation of $C$. odorata is found. The site is located in the dry zone of Sri Lanka between $8^{\circ} 18^{\prime}-8^{\circ} 23^{\prime} \mathrm{N}$ and $80^{\circ} 27^{\prime}-80^{\circ} 35^{\prime} \mathrm{E}$ and extends over 999.6 ha (2470 acres) area. Extent of the sanctuary has been defined in the gazette number 8370 of Sri Lankan government in 1938, yet no proper demarcated boundaries are documented [21].

Mihintale sanctuary receives an annual rainfall between 1,000-1500 mm/year from Northeast monsoon (NovemberJanuary) and intermonsoons (March-April, SeptemberOctober). The temperature fluctuates between $19^{\circ} \mathrm{C}$ and $38^{\circ} \mathrm{C}$ throughout the year with mean annual temperature of the study area being $27.3^{\circ} \mathrm{C}$. From February to September is the dry period with August being the warmest month of the year. The Southwest monsoon winds blow across Mihintale between May and September creating higher evaporation rate.

Mihintale sanctuary consists of different kinds of habitats; dry zone semievergreen undisturbed secondary forest patches, semievergreen disturbed secondary forests, scrublands, aquatic habitats, and highly degraded forest patches. $C$. odorata was observed as dense stands in around these habitats as well as the open forest margins.

2.3. Data Collection. A field survey was conducted to document potential pollinators in $C$. odorata shrubs in the area of $0.5 \mathrm{~km}^{2}$ semievergreen forest patch from the end of August 2014 to January 2015 which coincided with one flowering season of the weed $[9,16,22]$. Five (5) C. odorata inhabiting sites were selected to study flower visitors in Mihinthale Sanctuary. Vegetation density was calculated using the quadrate sampling method. Altogether, thirty (30) $5 \mathrm{~m} \times 5 \mathrm{~m}$ quadrats were layed randomly over stands in five study sites and number of $C$. odorata plants were counted in each quadrat. Counts were averaged and the density of C. odorata was calculated. Flowering density for $1 \mathrm{~m}^{2}$ was calculated by counting and averaging the number of flower heads fell within randomly layed another thirty (30) $1 \mathrm{~m} \times 1 \mathrm{~m}$ quadrates on C. odorata strands [23].

Direct observation method was followed to encounter potential insect visitors to $C$. odorata stands in sunny days with gentle breeze [24, 25]. Rainy days with heavy winds were deliberately avoided as pollinators are disturbed by these unsuitable climatic conditions. Prior to insect observations, flowers were observed carefully to confirm the readiness of flowers for pollination. Mature flowers from stands were sampled and observed to confirm that pollination has not been carried out $[4,26]$. This was easily determined by observing whether the stamens were disturbed and/or pollens were robbed by flower visitors. Fifteen (15) $1 \mathrm{~m} \times 1 \mathrm{~m}$ quadrats were selected randomly to be observed for insect visits. Observations and sampling insects were done from 0700 to 1800 for 7 days during the flowering season with the assistance of two observers. Visitation frequencies of each insect were noted during 30-minute period per hour. Insect samplings were done carefully using an insect net causing minimum as possible disturbance to the visiting insect communities. Therefore, five hours per each day was effectively utilized for insect survey. Interactions were confirmed if an insect touches anther or stigma of the flower [27] and visits were recorded irrespective to previous visits of the insect to the 
same plant. 30-minute settling period was given to the flower strands after each 30-minute capturing session to reduce the magnitude of disturbance created by the observers when capturing insects. Captured insect assemblages were taken to the laboratory to identify using available keys. [28]. Some specimens were identified to the genus by referring to the Invertebrate Systematic and Diversity Facility (ISDF) of the Department of Zoology, University of Peradeniya. At the laboratory, insects were checked for adhering pollens under the optical microscope to ensure whether the insects act as a potential pollinator or not. The insects that do not carry pollens on their bodies were excluded from the counts. The insect collections were deposited with the laboratory insect collection of the Rajarata University of Sri Lanka for further studies.

2.4. Data Analysis. The data gathered during the field survey was tabulated as insects in rows and visitation frequencies in columns. This contingency table was used to calculate different indices for describing the topography of the observed flower-insect interaction system.

Richness of insect visitor community was calculated using an abundance-based coverage estimator and richness of each insect order was calculated using Margalef's Index (M). Diversity of flower visiting insects was calculated using Maximum Likelihood Estimator of Shannon Diversity Index [29]. Diversity indices were calculated using the program SPADE developed by Chao and Shen [30].

Mean visitation frequencies were calculated for each insect observed in all 30 quadrats. The strength of interaction (T), which is indicative of the impact that each insect visitor exerts on flowers, was calculated following methods in Vazquez et al. [31]. Interaction strengths were checked for significant difference among flower visitor families and among flower visitor orders using a one-way ANOVA with residual analysis for normality and homoscedasticity of variance. All statistical analysis on interaction strength and visualization was done using MINITAB version16 (Minitab Inc., Coventry, $\mathrm{UK})$.

\section{Results}

Flowering occurred from October to December. Mean $C$. odorata vegetation density was $51.6 \pm 5.14$ while mean flowering density was $312.53 \pm 8.32$ across five sites. A total of 2271 flower visitations were recorded during 35 hours within 7 days of observation to $C$. odorata strands. Seventy-seven (77) insect flower visitors were recorded belonging to five major insect orders and twenty-five families (Table 1). Species richness of the $C$. odorata flower visitor community was $77.5 \pm$ 0.80 and species diversity was $4.183 \pm 0.02$.

Lepidopteran, Hymenopteran, and Dipteran diversity was higher than the diversity of Hemipterans and Coleopterans (Table 2). Altogether 32 Lepidopterans belonging to five families, 30 Hymenopterans belonging to eight families, 10 Dipterans in seven families, three Hemipterans in three families, and two Coleopterans in two families were identified as potential pollinators in the study system.
The interaction frequency of the pollinator species is highly correlated with the species strength (i.e., impact exerted on plant by its interacting partners) [31]. Thus, the most frequent flower visitors were thought to have a potentially high contribution for pollination of flowers and by that increasing their reproductive fitness or have higher amount of the pollinator reward from the flower. Orders Hymenoptera $(0.014 \pm 0.001)$, Diptera $(0.013 \pm 0.001)$, and Lepidoptera $(0.012 \pm 0.001)$ showed higher interaction strengths, respectively, while the order Coleoptera (0.009 \pm 0.001) had the least strength.

When comparing interaction strengths of flower visitors, family Apidae and Halictidae in the order Hymenoptera, family Syrphidae and Calliphoridae in order Diptera, and family Nymphalidae and Lycaenidae in the order Lepidoptera exhibited higher values in interaction strength scale. However, we did not detect any statistically significant differences between means of interaction strengths of flower visitor families as determined by one-way ANOVA $[F(24,52)=$ $0.69, p \geq 0.841]$. These results suggest that each insect visitor has equal importance in pollinating this invasive weed in dry forests.

Though there is no significant difference in pollinator strengths among insect visitors, top contributors were identified by ranking them in descending order using their impact exerted on the plant. Apis cerana, Apis dorsata, Ceratina binghami, Lasioglossum amblypygus, Antepipora sp. of order Hymenoptera, Episyrphus nectarinus of the order Diptera and Cepora nerissa, Junonia hierta, Melanitis leda, and Castallius rosimon of order Lepidoptera exhibited higher strength in pollination.

Observers identified two types of insect visitors exhibiting two different types of behaviors, namely, foragers on flowers and hovers. All insects who had shown high species strength over flowers were observed always on flowers. They all were observed to forage on closely arranged capitula of $C$. odorata passively loading sticky pollen grains on insects body. Thus, they were expected to facilitate passive transport of pollen grains more than sudden visitors who visit flower only for second or two.

\section{Discussion}

C. odorata is a weedy plant attracting a rich diversity of insects. Being available during major flowering season of the dry forest as well as the dry seasons, it provides an important source of pollen, nectar, and foraging grounds to insects who share the same habitat that they grow in. In general, insect communities associated with cosmopolitan invasive weeds differ from one habitat to another depending on availability of particular species and essentially on availability of other nectar and pollen sources [5]. Thus, the interactions are product of relative abundance of plant and animal components and environmental alterations. But, some authors argue that, irrespective of the species living in the habitat, exotic plant species reconstruct the plant-animal interactions by altering the resource availability to pollen or nectar gatherers [5]. In that context researchers can deduct that being an exotic plant in dry zone secondary forests C. odorata shares the 
TABLE 1: List of flower visitors in different orders and families observed in C. odorata stands in Mihintale Sanctuary and the frequency of visits. Rates presented are population means per $1 \times 1 \mathrm{~m}$ flower strands per hour $(n=15,35$ hours).

\begin{tabular}{|c|c|c|c|c|}
\hline Order & Family & Species & Frequency & $\mathrm{SD}( \pm)$ \\
\hline \multirow{30}{*}{ Hymenoptera } & \multirow{10}{*}{ Apidae } & Amegilla comberi & 2.33 & 1.53 \\
\hline & & Apis cerana & 22.67 & 1.15 \\
\hline & & Apis dorsata & 19.00 & 2.00 \\
\hline & & Apis florea & 14.00 & 2.65 \\
\hline & & Braunsapis sp. & 7.33 & 4.16 \\
\hline & & Ceratina binghami & 15.67 & 1.53 \\
\hline & & Thyreus insignis & 5.00 & 1.00 \\
\hline & & Trigona iridipennis & 9.00 & 1.00 \\
\hline & & Xylocopa ruficornis & 11.33 & 0.58 \\
\hline & & Xylocopa tenuiscapa & 4.00 & 1.00 \\
\hline & \multirow{5}{*}{ Halictidae } & Curvinomia iridiscens & 13.00 & 1.00 \\
\hline & & Hoplonomia westwoodi & 12.00 & 1.73 \\
\hline & & Lasioglossum amblypygus & 18.33 & 2.08 \\
\hline & & Leuconomia sp. & 12.33 & 1.53 \\
\hline & & Pachynomia sp. & 8.00 & 1.00 \\
\hline & \multirow{4}{*}{ Megachilidae } & Euaspis edentata & 12.00 & 1.00 \\
\hline & & Lithurgus atratus & 7.00 & 1.00 \\
\hline & & Megachile lanata & 12.67 & 2.08 \\
\hline & & Megachile vigilans & 4.33 & 0.58 \\
\hline & \multirow{2}{*}{ Chrysididae } & Chrysis oculata & 4.33 & 0.58 \\
\hline & & Stilbum cyanurum splendidum & 10.00 & 1.00 \\
\hline & \multirow{3}{*}{ Eumenidae } & Antepipona sp. & 15.00 & 1.00 \\
\hline & & Delta emarginatum & 7.00 & 1.00 \\
\hline & & Subancistrocerus sichelii & 2.00 & 1.00 \\
\hline & \multirow{4}{*}{ Sphecidae } & Ammophila atripes & 2.67 & 0.58 \\
\hline & & Sp. $1(H 1)$ & 13.67 & 1.53 \\
\hline & & Sp. $2(H 2)$ & 12.67 & 2.08 \\
\hline & & Sphex sp. & 7.00 & 1.00 \\
\hline & Scelionidae & Scolia jurinei Sauss & 3.00 & 1.00 \\
\hline & Vespidae & Sp. $1(H 8)$ & 3.67 & 2.52 \\
\hline \multirow{2}{*}{ Coleoptera } & Meloidae & Mylabris phalerata & 8.67 & 0.58 \\
\hline & Coccinellidae & Coccinellidae & 9.00 & 4.00 \\
\hline \multirow{10}{*}{ Diptera } & Syrphidae & Episyrphus nectarinus & 16.67 & 0.58 \\
\hline & \multirow{2}{*}{ Asilidae } & Cophinopoda chinensis & 13.67 & 2.52 \\
\hline & & Sp. $2(D 1)$ & 6.33 & 2.08 \\
\hline & Ulidiidae & Sp. $1(D 2)$ & 5.33 & 2.52 \\
\hline & Rhagionidae & Sp. $1(D 3)$ & 4.33 & 0.58 \\
\hline & Bombyliidae & Sp. $1(D 4)$ & 8.00 & 1.00 \\
\hline & \multirow{3}{*}{ Calliphoridae } & Sp. 1 (D5) & 10.00 & 2.65 \\
\hline & & Sp. $2(D 6)$ & 14.00 & 2.14 \\
\hline & & Sp. $3(D 7)$ & 12.33 & 1.12 \\
\hline & Tephritidae & Sp. $1(D 8)$ & 7.33 & 1.53 \\
\hline \multirow{3}{*}{ Hemiptera } & Reduviidae & Ectomocoris cordigera & 9.33 & 0.58 \\
\hline & Pyrrhocoridae & Sp. 1 (He1) & 6.33 & 2.08 \\
\hline & Scutelleridae & Rhynchium brunneum & 12.00 & 2.00 \\
\hline
\end{tabular}


TABLE 1: Continued.

\begin{tabular}{|c|c|c|c|c|}
\hline Order & Family & Species & Frequency & $\mathrm{SD}( \pm)$ \\
\hline \multirow{32}{*}{ Lepidoptera } & \multirow{4}{*}{ Papilionidae } & Pachliopta hector, Crimson Rose & 7.33 & 1.53 \\
\hline & & Papilio demoleus, Lime butterfly & 7.33 & 0.58 \\
\hline & & Papilio polymnestor, Blue Mormon & 3.67 & 2.08 \\
\hline & & Papilio polytes, Common Mormon & 14.00 & 4.36 \\
\hline & \multirow{8}{*}{ Pieridae } & Appias albina, Common Albatros & 12.33 & 1.53 \\
\hline & & Appeals Galen, Lesser Albatros & 3.33 & 1.53 \\
\hline & & Appias libythea, Stripped Albatros & 2.67 & 2.08 \\
\hline & & Catopsilia pyranthe, Mottled Emigrant & 8.33 & 2.52 \\
\hline & & Cepora nerissa, Common Gull & 17.33 & 2.89 \\
\hline & & Delias eucharis, Common Jezebel & 4.67 & 1.15 \\
\hline & & Eurema blanda, Three-Spot Grass Yellow & 10.33 & 3.21 \\
\hline & & Eurema hecabe, Common Grass Yellow & 2.33 & 1.53 \\
\hline & \multirow{10}{*}{ Nymphalidae } & Acraea violae, Tawny Coster & 8.00 & 1.00 \\
\hline & & Cirrochroa thais, Tamil Yeoman & 14.00 & 1.00 \\
\hline & & Danaus genutia, Common Tiger & 11.00 & 1.00 \\
\hline & & Euploea core, Common Crow & 14.67 & 2.08 \\
\hline & & Junonia hierta, Yellow Pansy & 17.33 & 1.15 \\
\hline & & Junonia iphita, Chocolate Soldier & 14.33 & 1.53 \\
\hline & & Melanitis leda, Common Evening Brown & 21.00 & 2.65 \\
\hline & & Neptis hylas, Common Sailer & 5.67 & 2.08 \\
\hline & & Parantica aglea, Glassy Tiger & 5.67 & 1.53 \\
\hline & & Ypthima ceylonica, White Four Ring & 7.67 & 1.15 \\
\hline & \multirow{5}{*}{ Lycaenidae } & Castalius rosimon, Common Pierrot & 15.00 & 3.61 \\
\hline & & Catochrysops strabo, Forget-me-not & 3.00 & 1.00 \\
\hline & & Jamides celeno, Common Cerulean & 8.33 & 0.58 \\
\hline & & Pachliopta hector, Crimson Rose & 8.00 & 4.36 \\
\hline & & Rapala manea, Slate Flash & 12.00 & 1.00 \\
\hline & \multirow{5}{*}{ Hesperiidae } & Ampittia dioscorides, Bush Hopper & 5.00 & 1.00 \\
\hline & & Badamia exclamationis, Brown Awl & 7.33 & 3.06 \\
\hline & & Iambrix salsala, Chestnut Bob & 8.33 & 1.53 \\
\hline & & Spialia galba, Indian Skipper & 4.67 & 2.08 \\
\hline & & Telicota colon, Pale Palm Dart & 5.33 & 2.52 \\
\hline
\end{tabular}

TABle 2: Diversity and richness of flower visitor orders in $C$. odorata stands in Mihintale Sanctuary (MLE: Maximum Likelihood Estimator of Shannon Weiner Diversity Index; M: Margalef's Index for measuring species richness).

\begin{tabular}{lccc}
\hline Order & Number of species & Diversity (MLE) & Richness (M) \\
\hline Coleoptera & 2 & $0.679 \pm 0.023$ & $0.351 \pm 0.025$ \\
Diptera & 10 & $2.227 \pm 0.012$ & $1.963 \pm 0.022$ \\
Hemiptera & 3 & $1.049 \pm 0.053$ & $0.602 \pm 0.004$ \\
Hymenoptera & 30 & $3.259 \pm 0.049$ & $5.113 \pm 0.058$ \\
Lepidoptera & 32 & $3.267 \pm 0.050$ & $5.469 \pm 0.062$ \\
\hline
\end{tabular}

same strength to alter topography of native interaction webs in its associated habitats. Thus, the current study bears an importance in determining the relative importance of the plant to the insect community and the strength it exerts on potential pollinators residing in the habitat. Also, being a plant with higher number of associated potential pollinators,
C. odorata exhibits its ability to act as pollinator sink in the growing environment.

Shihan and Kabir [32] argue that the attraction of the Butterflies in higher level may be due to presence of hexose sugars and amino acid rich nectar in the nectaries available in flowers. The flower bears minute amount of nectar more than many other flowers used by nectar gatherers. But, bees tend to forage on $C$. odorata as much as on any other nectar plant [33-36]. The reason may be the availability of large quantity of pollens and nectar collectively in one flower stand. Therefore, this weedy plant has been used as an important honey plant in commercial apiculture all over the world $[33,35,36]$. By looking at our insect visitor checklist compiled for dry zone forests shown above it is concluded that wild bees are also attracted to the plant as much as the domesticated bees such as Apis cerana, Apis dorsata, or Trigona iridipennis.

In addition to the nutrients and the reward for the pollinators, the shape of the flowers was also observed to have well adapted to facilitate the visitors. Floral heads create a fine 
landing stage for many flower visitors and closely arranged flowers in the stands facilitate movement of insects from flower to flower easily or efficiently.

The current study does not suggest very strong interaction between flower visitors and the plant C. odorata. However, the top potential contributors were identified, including butterflies and adding bees and flies to the global checklist of interacting species with $C$. odorata. Since the dry forests generally experience a scarcity of flowering plants during the dry spell and the heavy rains, generalist insect foragers may have to use whatever floral resources available in the system to ensure their survival and continuation of generations. Therefore, almost equal visitation frequencies and interaction strengths can occur due to this dependence of the floral visitors on the available resources. Accordingly, this plant can be viewed as a refuge for insects when it is flowering in invaded habitats, where no other plants are available to give out pollen and/or nectar in the habitat.

\section{Competing Interests}

The authors declare that there is no conflict of interests regarding the publication of this paper.

\section{Authors' Contributions}

D. G. R. M. M. Kaushalya Rathnayake and W. M. G. Asanga

S. T. B. Wijetunga contributed equally to this work.

\section{Acknowledgments}

The authors are also grateful to the respective Heads of the Department of Biology, Faculty of Applied Sciences, Rajarata University of Sri Lanka, Mihintale, and the Department of Zoology, University of Peradeniya, for their support in conducting the study and Dr. Inoka Karunarathne of the Department of Zoology, Faculty of Science, University of Peradeniya, for the invaluable support given for the identification of pollinators and granting permission to use the Invertebrate Systematic and Diversity Facility (ISDF) of the Department. Professor Tom Chapman, Travis Heckford, and Maria Esther Neito Blazquez of the Memorial University of Newfoundland, Canada, are highly acknowledge for their support in producing the manuscript.

\section{References}

[1] D. P. Abrol, Pollination Biology: Biodiversity Conservation and Agricultural Production, Springer, 2011.

[2] L. Pijl, The Principles of Pollination Ecology, Pergamon Press, Oxford, UK, 1979.

[3] L. Van der Pijl, Principles of Dispersal, Springer, Berlin, Germany, 1982.

[4] K. Faegri and L. Van der Pijl, The Principles of Pollination Ecology, William Clowes \& Sons Limited, London, UK, 3rd edition, 1979.

[5] J. Ghazoul, "Alien abduction: disruption of native plantpollinator interactions by invasive species," Biotropica, vol. 36 , no. 2, pp. 156-164, 2004.
[6] M. H. Allsopp, W. J. De Lange, and R. Veldtman, "Valuing insect pollination services with cost of replacement," PLoS ONE, vol. 3, no. 9, Article ID e3128, 2008.

[7] J. Bascompte and P. Jordano, "Plant-animal mutualistic networks: the architecture of biodiversity," Annual Review of Ecology, Evolution, and Systematics, vol. 38, pp. 567-593, 2007.

[8] J. Memmott, N. M. Waser, and M. V. Price, "Tolerance of pollination networks to species extinctions," Proceedings of the Royal Society of London B: Biological Sciences, vol. 271, no. 1557, pp. 2605-2611, 2004.

[9] P. V. Lakshmi, A. J. S. Raju, D. J. Ram, and K. V. Ramana, "Floral biology, psychophily, anemochory and zoochory in Chromolaena odorata (L.) King and the Robins (Asteraceae)," Pakistan Journal of Scientific and Industrial Research, vol. 54, pp. $1-8,2011$.

[10] C. C. Daehler, "Performance comparisons of co-occurring native and alien invasive plants: implications for conservation and restoration," Annual Review of Ecology, Evolution, and Systematics, vol. 34, pp. 183-211, 2003.

[11] A. Traveset and D. M. Richardson, "Biological invasions as disruptors of plant reproductive mutualisms," Trends in Ecology \& Evolution, vol. 21, no. 4, pp. 208-216, 2006.

[12] E. Moragues and A. Traveset, "Effect of Carpobrotus spp. on the pollination success of native plant species of the Balearic Islands," Biological Conservation, vol. 122, no. 4, pp. 611-619, 2005.

[13] L. Gautier, "Taxonomy and distribution of a tropical weed: Chromolaena odorata (L.) R. King \& H. Robinson," Candollea, vol. 47, pp. 645-662, 1992.

[14] A. De Rouw, "The invasion of Chromolaena odorata (L.) King \& Robinson (ex Eupatorium odoratum), and competition with the native flora, in a rain forest zone, south-west Cote d'Ivoire," Journal of Biogeography, vol. 18, no. 1, pp. 13-23, 1991.

[15] R. C. McFadyen and B. Skarratt, "Potential distribution of Chromolaena odorata (siam weed) in Australia, Africa and Oceania," Agriculture, Ecosystems \& Environment, vol. 59, no. 1-2, pp. 89-96, 1996.

[16] R. Muniappan and M. Marutani, "Ecology and distribution of chromolaena odorata in Asia and the pacific," in Proceedings of the 1st International Workshop on Biological Control of Chromolaena Odorata, pp. 21-24, Agricultural Experiment Station, University of Guam, Bangkok, Thailand, 1988.

[17] D. J. Kriticos, T. Yonow, and R. E. McFadyen, "The potential distribution of Chromolaena odorata (siam weed) in relation to climate," Weed Research, vol. 45, no. 4, pp. 246-254, 2005.

[18] S. Inderjit, Invasive Plants: Ecological and Agricultural Aspects, Springer, 2006.

[19] R. Muniappan, G. Reddy, and P.-Y. Lai, "Distribution and biological control of chromolaena odorata," in Invasive Plants: Ecological and Agricultural Aspects, pp. 223-233, Birkhäuser, Basel, Switzerland, 2005.

[20] G. A. Epp, "The seed bank of Eupatorium odoratum along a successional gradient in a tropical rain forest in Ghana," Journal of Tropical Ecology, vol. 3, no. 2, pp. 139-149, 1987.

[21] S. M. W. Ranwala and P. G. I. Thushari, "Current status and management options for invasive plants at the Mihintale Wildlife sanctuary," Journal of the National Science Foundation of Sri Lanka, vol. 40, no. 1, pp. 67-76, 2012.

[22] C. Zachariades, M. Day, R. Muniappan, and G. Reddy, "Chromolaena odorata (L.) king and robinson (Asteraceae)," in Biological Control of Tropical Weeds Using Arthropods, pp. 130160, Cambridge University Press, Cambridge, Mass, USA, 2009. 
[23] M. Stang, P. G. L. Klinkhamer, and E. Van der Meijden, "Asymmetric specialization and extinction risk in plant-flower visitor webs: a matter of morphology or abundance?" Oecologia, vol. 151, no. 3, pp. 442-453, 2007.

[24] A. M. Basilio, D. Medan, J. P. Torretta, and N. J. Bartoloni, "A year-long plant-pollinator network," Austral Ecology, vol. 31, no. 8, pp. 975-983, 2006.

[25] K. Jędrzejewska-Szmek and M. Zych, "Flower-visitor and pollen transport networks in a large city: structure and properties," Arthropod-Plant Interactions, vol. 7, no. 5, pp. 503-516, 2013.

[26] K. Faegri and L. Van der Pijl, Principles of Pollination Ecology, Elsevier, 2013.

[27] Y. L. Dupont and J. M. Olesen, "Ecological modules and roles of species in heathland plant-insect flower visitor networks," Journal of Animal Ecology, vol. 78, no. 2, pp. 346-353, 2009.

[28] S. G. Potts, A. Dafni, and G. Ne'eman, "Pollination of a core flowering shrub species in Mediterranean phrygana: variation in pollinator diversity, abundance and effectiveness in response to fire," Oikos, vol. 92, no. 1, pp. 71-80, 2001.

[29] A. Chao and S.-M. Lee, "Estimating the number of classes via sample coverage," Journal of the American Statistical Association, vol. 87, pp. 210-217, 1992.

[30] A. Chao and T.-J. Shen, "Nonparametric estimation of Shannon's index of diversity when there are unseen species in sample," Environmental and Ecological Statistics, vol. 10, no. 4, pp. 429-443, 2003.

[31] D. P. Vazquez, S. B. Lomáscolo, M. B. Maldonado et al., "The strength of plant-pollinator interactions," Ecology, vol. 93, no. 4, pp. 719-725, 2012.

[32] T. R. Shihan and N. Kabir, "Butterfly diversity in relation to Chromolaena odorata (L.) King and H.E. Robins as a nectar plant from two selected regions of Bangladesh," Journal of Entomology and Zoology Studies, vol. 3, no. 3, pp. 258-264, 2015.

[33] P. Akratanakul, Beekeeping in Asia, Food \& Agriculture Organization, 1986.

[34] P. Latham, "Manuals for bee forage in Tanzania and Congo," Bee World, vol. 82, no. 2, pp. 57-59, 2001.

[35] A. F. Hill, "American honey plants: together with those which are of special value to the beekeeper as sources of pollen. Frank C. Pellett," The Quarterly Review of Biology, vol. 23, no. 4, pp. 354-354, 1948.

[36] R. Thapa and S. Wongsiri, "Eupatorium odoratum: a honey plant for beekeepers in Thailand," Bee World, vol. 78, pp. 175-178, 1997. 

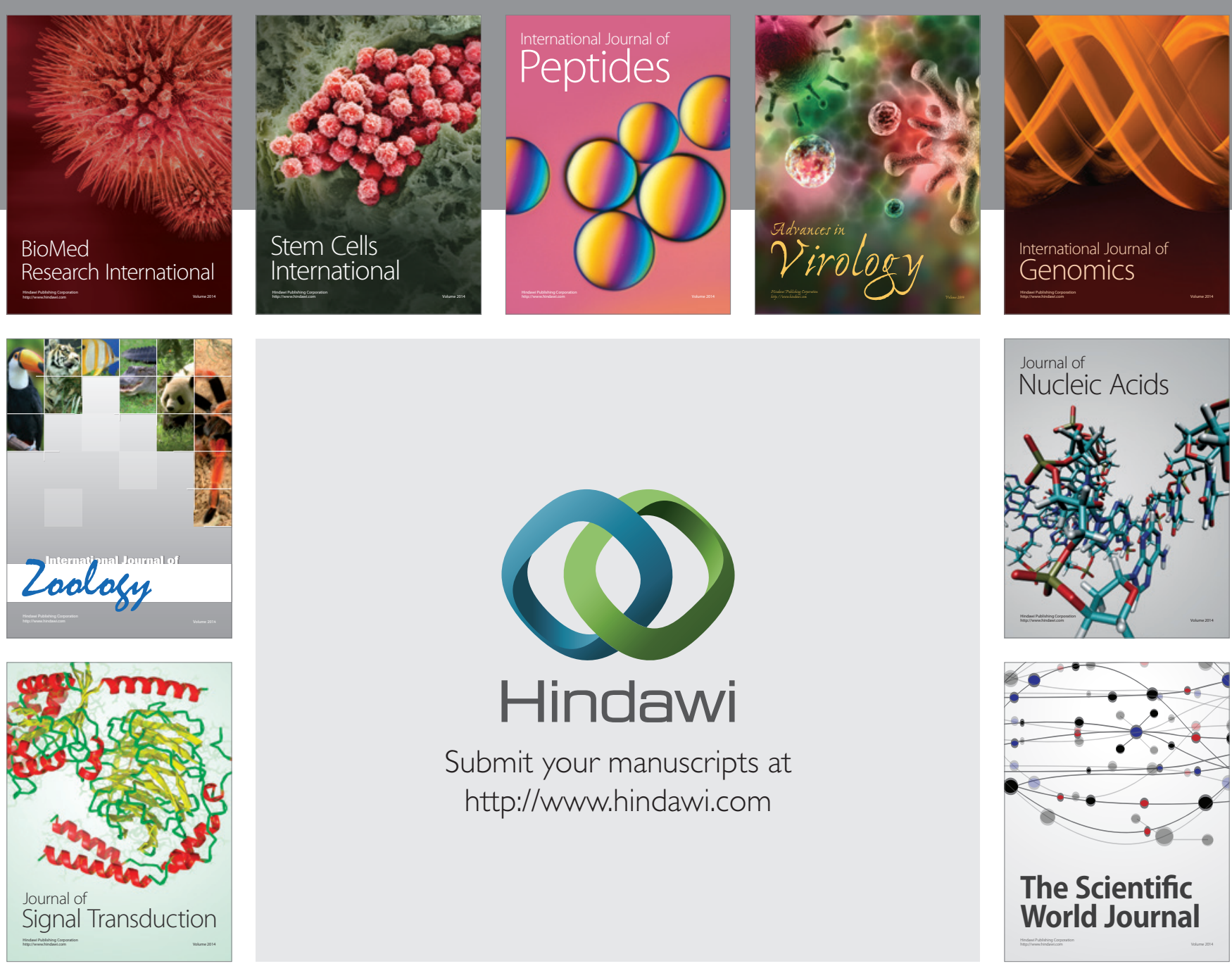

Submit your manuscripts at

http://www.hindawi.com
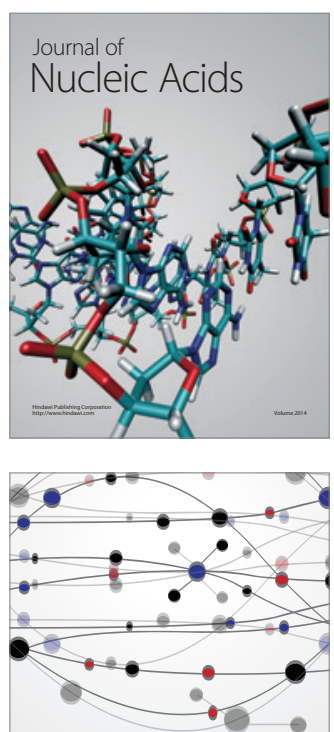

The Scientific World Journal
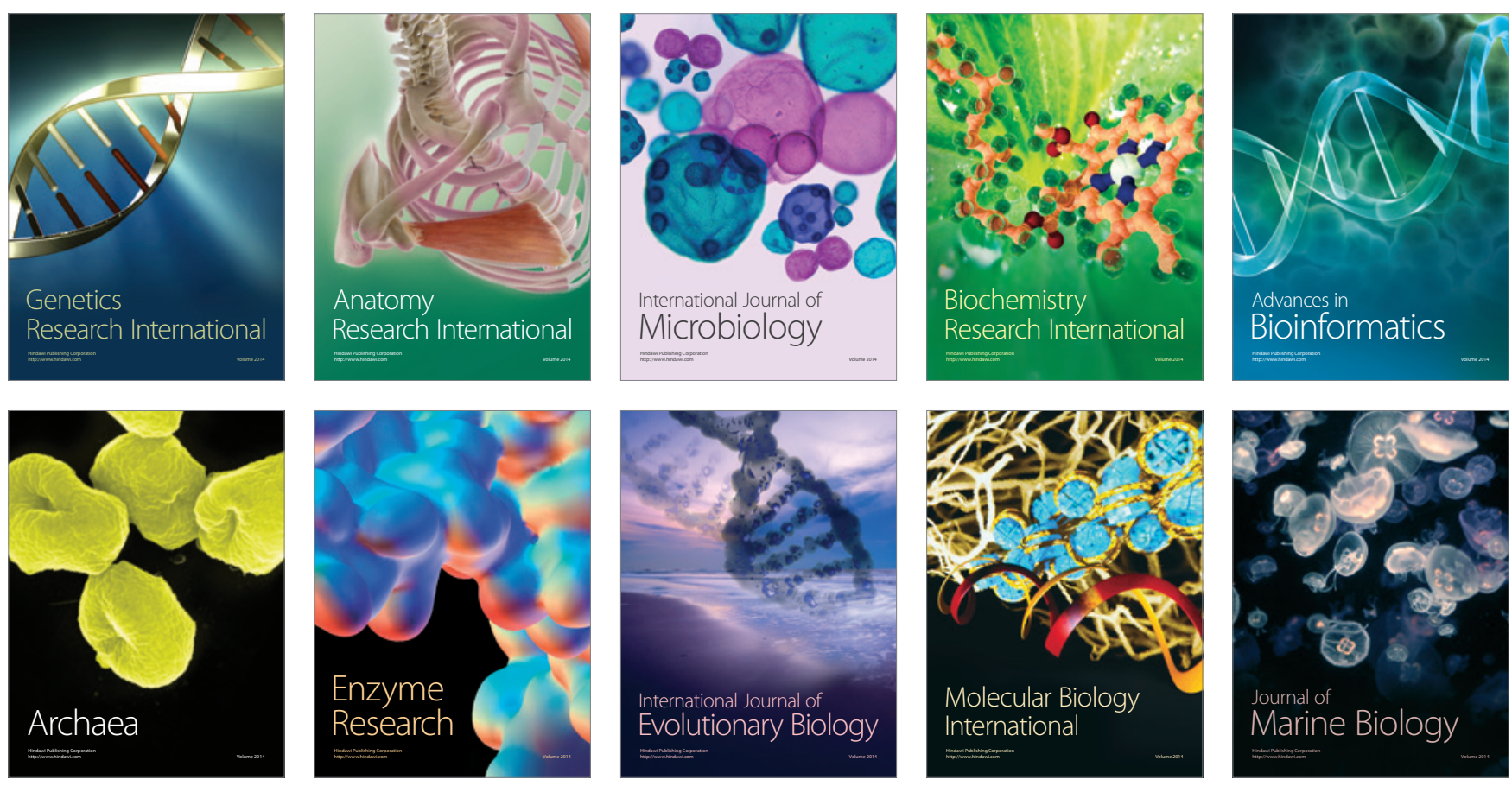